CZU 342:004.738.5

https://doi.org/10.52507/2345-1106.2021-1.13

ПРАВОВЫЕ ПРОБЛЕМЫ ДОСТУПА В ИНТЕРНЕТ В РЕСПУБЛИКЕ МОЛДОВА

кУЧУк Валерий, Доктор права

ПУШКАШ Виктор, Доктор права, Заведующий кафедрой публичного права Европейского Университета Молдова

\begin{abstract}
АННОТАЦИЯ
В Республике Молдова Интернет стал основным информационным ресурсом. Это, в свою очередь, наряду с предоставлением человеку многих преимуществ и возможностей, Интернет конвейерно генерирует все больше и больше правовых проблем. Основная причина этому нарушение фундаментальных прав человека, нарушение интересов общества и государства. В статьи приводятся аргументы о необходимости регулирования Интернета, начиная с Конституции Республики Молдова, и заканчивая действующим законодательством. На взгляд авторов, право на Интернет должно быть закреплено и в специальном законе, который предусмотрел бы условия допуска в Интернет, обязанности операторов услуг и пользователей, ограничения и гарантии ответственного пользования Интернета.
\end{abstract}

Ключевые слова: Республика Молдова, Конституция, Закон, Интернет.

\title{
LEGAL PROBLEMS OF INTERNET ACCESS IN THE REPUBLIC OF MOLDOVA
}

KUCHUK Valery, Doctor in Law

PUSHKASH Victor, Doctor in Law, Head of the Department of Public Law European University Moldova

\begin{abstract}
SUMMARY
In the Republic of Moldova, the Internet has become the main information resource. This, we can appreciate that in comparison with providing a person with many advantages and opportunities, the Internet generates more and more legal problems. The main reason for this is violation of fundamental human rights, violation of the interests of society and the state. The articles provide arguments about the need to regulate the Internet, starting with the Constitution of the Republic of Moldova and ending with the current legislation. In the opinion of the authors, the right to the Internet should also be enshrined in a special law, which would provide for the conditions for access to the Internet, the obligations of service operators and users, restrictions and guarantees of responsible use of the Internet.
\end{abstract}

Key words: The Republic of Moldova, the Constitution, Law, Internet.

Признавая значимую роль Интернета в современном мире, тем не менее надо признать, что Интернет - это в том числе инструмент нарушения любых гражданских прав. При том что это совершенно новое качество нарушения по сравнению с тем, что люди, общество и государство имели раннее.

К тому же сегодня остро стоит как организационно-правовая проблематика сети Интернет, так и наличие специальных проблем которые возникли в условиях всеобщей пандемии, и которые заставили уйти в Интернет и экономику, и образование, и государственное управление, и многие другие сферы деятельности человека, даже сектор юстиции.

И если систематизировать проблемы Интернета, мы раздели их на два блока - общие и специальные.

К общим проблемам Интернета относятся: а) проблема юрисдикции,

б) проблема суверенности,

c) проблема государственного управления,

д) проблема ответственности,

е) проблема доступа в Интернет, и,

ф) проблема ограниченного использования Интернета - проблема ограничений.

А если касаться специальных проблем, то только на примере юстиции, можно указать специфику доступа и специфику использования Интернета. Здесь можно указать проблему правосубъектности, участия тех или иных лиц в данных общественных правоотношениях, складывающихся с доступом и использованием сети Интернет.

Также, мы имеем и проблему электронной подписи, и прозрачности работы суда и рассмотрения дел, проблема обеспечения доказательств, проблема фиксации времени и места 
действий в сети, проблема личных данных, и т.д. и т.п. И от решения каждой из этих проблем, сформируется доверие или наоборот, недоверие к сектору юстиции и к тем институтам работающих в нем.

Кроме этого, несомненно, правоотношения между актёрами Интернета и государством, а также государством и международные организации, которые прекрасно понимают серьезность неурегулированности вопросов в сети Интернет и необходимость решения правовых возникающих проблем.

Помимо указанных общих проблем сети Интернет, существуют специальные, уникальные проблемы сети, которые не имеют аналогов в реальном мире, в реальных общественных отношениях. В первую очередь, это проблема электронной коммерции. Далее, проблематика рекламы в сети, электронная почта, предпринимательство, налогообложение, электронная почта и электронное управление.

И все вышеобозначенные группы генерируют вопросы и проблемы, все они нуждаются в нормативном регулировании. Иначе генерация проблем доступа и использования сети интернет поставлена на поток.

Это проблема соблюдения авторских прав в сети и прав на товарные знаки. А также проблема манипуляции информацией с нарушением прав правообладателей.

Следующей проблемой, является проблема ответственности за содержание информации клиентов и пользователей на серверах провайдеров операторов связи и провайдеров информационных услуг. Далее - это проблема безопасности (криптография, защита данных, политика шифрования и т.д.). Кроме этого, смежный вопрос это проблема обеспечения и осуществления цензуры, как частной, со стороны каких-либо лиц, со стороны сетевого сообщества, так и со стороны государства и государственных организаций.

Вопрос нормотворческой деятельности в плане суверенности сети, стоит крайне остро. И это происходит на наш взгляд потому как государственный суверенитет РМ в сети Интернет, принцип суверенности национальной сети Интернета - не закреплен ни в каких всевозможных нормативноправовых актах, и в первую очередь отсутствует конституционный базис правового регулирования.

Более того, понимание данного вопроса, на самом деле отсутствует как у регуляторов, так и у пользователей сети.

Далее, смежный с ним принцип первичности закона также не соблюдается, потому как мы считаем, что сперва необходимо закрепить соответствующие позиции данных общественных правоотношений в законе, а уже после этого их можно доверять определенным складывающимся общественным отношениям саморегуляции или регулирование на уровне пользователей Интернета.

Имея в виду вышеописанное, главными правовыми проблемами Интернета это:
- Конституционное регулирование Интернета.

- Проблемы, связанные с защитой прав человека в сети Интернет.

- Проблемы правового регулирования Интернета и собственности в сети (в том числе исключительных прав на сетевой адрес - доменное имя).

- Защита персональных данных.

- Правовое регулирование электронной торговли в сети Интернет

- Распространение экстремистских материалов в сети Интернет.

- Пропаганда и продажа наркотических средств и психотропных веществ.

- Клевета в сети Интернет.

- Мошенничество в сети Интернет.

Таким образом можно четко определить, что Интернет-регулированию необходимо развитие:

- конституционных основ проблемы допуска в сеть Интернета;

- нормативно-правовой базы Интернета в РМ;

- судебную практику решения правовых проблем доступа в Интернет и пользования сети.

Мы уверены, что решение проблемы развития законодательства РМ о доступе в Интернет, обеспечение стабильности, совместимости, доступности и открытости Интернета, нейтральности и суверенности сети, доступ к информации и знаниям, конфиденциальность, кибербезопасность и трансграничное развитие информационнокоммуникационных технологий, способны сформировать основу долгосрочного развития Молдовы и ее граждан.

Мы поддерживаем неоднократно высказанное мнение исследователей [1], которые считают, что право на доступ в Интернет должно включать следующие составляющие:

- свобода выбора и использования программного обеспечения и технических устройств, с которых осуществляется доступ в Сеть;

- качественный сервис и беспрепятственный доступ к технологическим возможностями, предоставляемым Интернетом;

- требование сетевой нейтральности;

- запрет любой дискриминации трафика или ухудшения качества услуг;

- обеспечение максимального охвата для доступа в Интернет с мобильных устройств и в общественных местах;

- и другие.

В то же время мы поддерживаем мнение ученых, которые в своих исследованиях [2] считают необходимыми при свободном допуске в Интернет внедрение правовых ограничений и гарантий необходимые для:

-защиты конституционного строя, обороны страны и безопасности государства;

- защиты нравственности и здоровья граждан;

- обеспечения прав и свобод других лиц;

- ограничение конституционной свободы слова.

Однако, считаем, что любые ограничения прав и свобод могут иметь место только в соответствии со 
ст. 54 Конституции РМ. Тем более что конституционная практика выработала определенные четкие критерии, нами раннее описанные [3]:

- ограничение прав или свобод могут иметь тесто только на основании конкретного органического закона;

- ограничения не должны противоречить международному праву;

ограничения могут касаться только определенного права и не противоречить другим правам и свобод;

- некоторые права носят абсолютный характер и не могут быть ограничены;

- ограничения могут носить исключительный характер;

- ограничения могут быть направлены на значимые интересы: государственной безопасности, конституционного строя, территориальная целостность и другие;

- ограничения могут быть направлены против массовых беспорядков, преступности, предотвращения нарушений прав, свобод и достоинство других граждан и др.;

- ограничения должны быть пропорциональны ситуациям и не могут задевать других прав или свобод;

- ограничения должны носить временный характер.

Таким образом, мы считаем, что вопрос свободного доступа граждан в Интернет в Республике Молдова, необходимо осуществлять соблюдая следующие условия:

- строгое соблюдение конституционных прав человека;

- внедрение законодательным образом концепции свободного и открытого Интернета, согласно принципам ООН, Декларацией прав человека, Регламентом (ЕС) 2015/2120) и действующим законодательством Республики Молдова;

- ограничение (блокирование) доступа лиц к определенному контенту в сети Интернет строго в соответствии с законом.

Казуальный случай о конституционном рассмотрении вопроса о праве на информацию.

Право на информацию тождественно праву на доступ в Интернет. Однако, вопрос о праве на информацию в Республике Молдова был рассмотрен Конституционным Судом РМ, который 22 июня 2015 года принял Постановления №19 «о толковании ч.(3) ст.34 Конституции Республики Молдова (право на информацию)».

Вследствие рассмотрения, Конституционный Суд РМ определил, что:

- право лица на доступ к любой информации, касающейся общественных дел, не может быть ограничено. Данное право включает два аспекта: право запрашивать и право получать информацию.

- право на информацию является основным правом человека, поскольку развитие личности в обществе, осуществление свобод, предусмотренных Конституцией, включая свободу мысли, мнения, творчества, свободу публичного выражения посредством слова, изображения или иными возможными способами, предполагает и возможность восприятия информации об общественной, политической, экономической, научной, культурной жизни и др.

- право на информацию является условием, предваряющим осуществление других прав: политических, экономических и социальных прав; права на защиту личной жизни; права участия в общественной жизни; права на справедливое судебное разбирательство и др.

- высший закон содержит нормы, нацеленные на продвижение участия в общественной жизни. Ст.2 ч. (1) и ст.39 Конституции закрепляют право на участие в управлении общественными делами.

- модели демократического участия требуют, чтобы граждане были достаточно хорошо осведомлены, чтобы они смогли эффективно участвовать в управлении.

- взаимосвязь между правом на информацию и правом участия в управлении общественными делами получила признание в практике международных организаций по правам человека

- ЕСПЧ указал на взаимосвязь между правом на информацию и правом на справедливое судебное разбирательство в гражданском судопроизводстве

- право на информацию может обусловить и реализацию экономических, социальных и культурных прав.

- согласно ст.54 ч. (2) Конституции осуществление прав и свобод не подлежит никаким ограничениям, кроме тех, которые предусмотрены законом,

Вместе с тем Конституционный Суд четко указал, на наш взгляд ошибочно, что:

- право на информацию - это право запрашивать информацию от публичных органов и учреждений;

- под правом доступа к любой информации имеются в виду порядок, способы и условия управления государственными делами;

- отказ в предоставлении доступа к информации может стать нарушением права на свободу выражения, гарантированного ст.10 Конвенции.

Таким образом, сфера понимания и использования термина «право на информацию», государственные и общественные правоотношения исполнения права на информацию, была недопустимо усечена Конституционным Судом.

Более того, данное постановление Конституционного Суда не учитывает:

- Резолюцию Генеральной Ассамблеи ООН (A/RES/60/252) от 26 апреля 2006г о создании Форум IGF для координации деятельности различных заинтересованных участников в целях обеспечения безопасного и надежного функционирования и использования интернета и обеспечения открытого и свободного доступа к ресурсам интернета;

- Резолюцию Генеральной Ассамблеи ООН от 3 июня 2011г о признание права на доступ в интернет 
одним из неотъемлемых прав человека;

- Соглашение об ассоциации РМ с ЕС от 16 июля 2014г;

- Директиву 2000/31/CE от 8 июня 2000 об электронной коммерции и входит в противоречии с Регламентом Европейского Парламента и Совета Европейского Союза 2015/2120 от 25 ноября 2015 г. об установлении мер относительно открытого доступа в Интернет.

Мы считаем, что правовой эффект от ПКС от 22 июня 2015г «о толковании ч. (3) ст.34 Конституции Республики Молдова (право на информацию)» негативный, поскольку:

- создает конституционную неопределенность и указывает на отсутствие конституционной защиты права допуска в Интернет;

- подчеркивает несоответствие национальных норм международным правовым нормам о допуске в Интернет;

Таким образом, ПКС от 22 июня 2015г «о толковании ч.(3) ст.34 Конституции Республики Молдова (право на информацию» противоречит самой Конституции и согласно ст.7 которая гласит что «Ни один закон или иной правовой акт, противоречащче положениям Конституции, не имеют юридической силь»», данное постановление является ничтожным.

Заключение. Без сомнения, право на доступ в Интернет должно быть признано как одно из основных прав человека, и данное право должно быть прописано в Конституции Республики Молдова.

Можно констатировать что есть страны, которые усовершенствовали свои правовые системы и в этой проблеме, начиная с законов, подзаконных актов и прежде всего внеся изменения в своих национальных конституциях.

На наш взгляд, имеется острая необходимость по совершенствованию и Конституции Республики Молдова, принятой 29 июля 1994 года.

Мы считаем, что во втором разделе Конституции - «Основные права, свободы и обязанности» можно было бы ввести отдельную статью - «Право на Интернет», в которой необходимо признать право на Интернет, как одно из фундаментальных прав человека и условия реализации этого права. А можно внести и дополнения к отдельным статьям действующей Конституции, в частности, в статье 30 - «Тайна переписки», и в части (4) ст. 34 Конституции РМ - «Право на информацию» [4].

Также, имеется необходимость в специальном Законе об основах регулирования Интернета, который бы:

- определил правовые отношения между участниками процесса регулирования Интернета и их функции при осуществлении регулирования,

- установил принципы и определил основные направления регулирования правовых отношений, связанных с использованием Интернета,

- установил правила определения места и времени совершения юридически значимых действий при использовании Интернета,

- нормативно установил гарантии соблюдения прав человека, в том числе обеспечение свободы доступа к информации, информационную безопасность,

- установил порядок государственной поддержки работы и развития Интернета.

В заключение подчеркиваем, что Интернет является самым динамичным средством, и поэтому любые системы или механизмы, предназначенные для управления использования интернета, должны быть открыты для всех, обеспечивая конституционную защиту прав человека. Ведь, конституционное и нормативное регулирование обеспечения доступа к Интернет-ресурсам, является злободневной задачей для государственных институтов власти, поскольку речь идет об одном из основных прав человека, и в свете современных вызовов, именно реализация права на доступ в Интернет, в состояние обеспечить соответствующее дальнейшее соблюдение других конституционных прав и свобод граждан Республики Молдова.

\section{Библиографические сноски:}

1. Horten Monica. Raport privind neutralitatea internetului în Republica Moldova. Chisinau, 2016. https://idsi.md/files/CoE_Network_neutrality_Report_Moldova.pdf (vizitat 11.01.2021);

2. Щербович А.А. «Конституционные гарантии свободы слова и права доступа к информации в сети Интернет» (https.//www.dissercat.com/) (vizitat 23.01.2021;

3. Pușcaș V., Rolul Curții Constituționale în respectarea limitelor restrîngerii exercițiului unor drepturi sau libertății prevăzute de Constituția RM/ „Justiția constituțională” nr. 3, 2005. 2020 .

4. Пушкаш В., Кучук В. Доступ в интернет: право, гарантии и ограничения. Chișinău: Legea și viața, nr.12, 